\title{
EFISIENSI PENGIRIMAN BENIH IKAN LELE DUMBO (CLARIAS GARIEPINUS) DENGAN KEPADATAN YANG BERBEDA DALAM PACKING TUKKA-KOTA PINANG
}

\author{
Benri Situmorang
}

Akper Pemkab Tapanuli Utara

benrisitumorang@yahoo.co.id

\begin{abstract}
Abstrak
Ikan lele dumbo (Clarias gariepinus) mempunyai kelebihan dan keunggulan yang khas, bila dibandingkan dengan ikan air tawar yang lainnya, yaitu pemeliharaan yang murah, mudah, serta dapat hidup di air yang kurang baik, cepat besar dalam waktu yang relatif singkat, kandungan gizi yang tinggi dalam setiap ekornya, juga memiliki rasa daging yang khas dan lezat yang tidak terdapat pada ikan lainnya. Peluang usaha ikan lele dumbo (Clarias gariepinus) tidak terbatas untuk memenuhi kebutuhan konsumen rumah tangga, restoran atau rumah makan, namun setiap sub sistem dalam budidaya memiliki peluang pasar, artinya budidaya ikan lele dumbo (Clarias gariepinus) tidak harus dilakukan dari pembenihan, pendederan dan pembesaran dalam satu unit usaha. Packing merupakan sistem yang dikoordinasi untuk menyiapkan barang atau suatu produk untuk ditransportasikan, didistribusikan, disimpan, dijual, dan dipakai. Packing yang ideal terdapa pada perlakuan pertama $\left(\mathrm{P}_{1}\right)$ dimana kepadatan packing yaitu 1.000 ekor, dengan kelulusan hidup benih ikan lele dumbo (Clarias gariepinus) mencapai $98.83 \%$. Packing yang efesien terdapat di $\left(\mathrm{P}_{3}\right)$ dengan kepadatan 1.500 bila dibandingkan dengan $\left(\mathrm{P}_{1}\right) 1.000$ dan $\left(\mathrm{P}_{2}\right) 1.250$ ekor benih ikan lele dumbo (Clarias gariepinus). Karena setelah dilakukan perhitungan keuntungan lebih baik bila di bandingkan dengan $\left(\mathrm{P}_{1}\right)$ 1.000 dan $\left(\mathrm{P}_{2}\right) 1.250$.
\end{abstract}

Kata Kunci: Efisiensi, Ikan Lele Dumbo dan Packing

\begin{abstract}
The fish of African catfish (Clarias gariepinus) has advantages and benefits of a typical, compared with freshwater fish, namely the maintenance of a cheap, easy, and can live in water that is less good, big fast in a relatively short time, nutrient content high in each tail, also has a distinctive flavor and delicious meats that are not on other fish. Business opportunities fish of African catfish (Clarias gariepinus) is not limited to meet the needs of domestic consumers, restaurant or restaurant, but each sub-system in the cultivation of market opportunities, which means the cultivation of fish of African catfish (Clarias gariepinus) should not be done from a hatchery, nursery and enlargement in a single business unit. Packing is a coordinated system of preparing goods or a product to be transported, distributed, stored, sold and used. Packing ideal terdapa the first treatment (P1) where the density of packing of 1,000 head, with the survival of fish seed of African catfish (Clarias gariepinus) reached $98.83 \%$. Packing an efficient contained in (P3) with a density of 1500 compared to (P1) 1000 and (P2) 1,250 fry fish of African catfish (Clarias gariepinus). Because after calculation better advantage when compared with (P1) 1000 and (P2) 1250 .
\end{abstract}

Keywords: Efficiency, Catfish Dumbo and Packing

\section{PENDAHULUAN}

Indonesia memiliki sumberdaya perikanan yang sangat potensial untuk dikembangkan, baik di wilayah perairan tawar (darat), payau maupun perairan laut. Hal ini didukung oleh potensi perairan umum yang begitu luas dan belum dimanfaatkan untuk usaha perikanan secara optimal. Ikan lele dumbo (Clarias gariepinus) merupakan salah satu 
komoditas air tawar yang memiliki daya serap pasar yang tinggi, bila potensi tersebut dimanfaatkan secara optimal dan benar, maka akan dapat meningkatkan pendapatan petani ikan, membuka lapangan kerja, memanfaatkan daerah potensial, serta membantu menjaga kelestarian sumberdaya hayati (Khairuman, 2002)

Ikan lele dumbo (Clarias gariepinus) mempunyai kelebihan dan keunggulan yang khas, bila dibandingkan dengan ikan air tawar yang lainnya, yaitu pemeliharaan yang murah, mudah, serta dapat hidup di air yang kurang baik, cepat besar dalam waktu yang relatif singkat, kandungan gizi yang tinggi dalam setiap ekornya, juga memiliki rasa daging yang khas dan lezat yang tidak terdapat pada ikan lainnya. Peluang usaha ikan lele dumbo (Clarias gariepinus) tidak terbatas untuk memenuhi kebutuhan konsumen rumah tangga, restoran atau rumah makan, namun setiap sub sistem dalam budidaya memiliki peluang pasar, artinya budidaya ikan lele dumbo (Clarias gariepinus) tidak harus dilakukan dari pembenihan, pendederan dan pembesaran dalam satu unit usaha. Kenyataan ini dapat kita lihat langsung di lapangan. Sebagian besar yang lain justru membudidayakan ikan lele dumbo (Clarias gariepinus) dengan hanya mengusahakan pada satu atau dua sub sistem (Khairuman, 2002).

Hal ini berarti ada petani yang hanya bertindak sebagai pembenih, ada yang hanya bertindak sebagai pendeder, dan selebihnya bergerak hanya di bidang usaha pembesaran. Dengan demikian, peluang usaha di setiap sub sistem terbuka lebar karena kegiatan pendederan dan pembesaran tidak dapat berjalan jika tidak ada kegiatan pembenihan. Dampak positif dari hal ini adalah mendorong petani ikan lele dumbo (Clarias gariepinus) untuk mengubah pola usahanya dari usaha sampingan menjadi usaha pokok.

Masyarakat Indonesia dahulu hanya mengenal jenis ikan lele lokal, kemudian sekitar tahun 1985 jenis ikan lele masuk ke Indonesia, kualitas ikan lele dumbo (Clarias gariepinus) yang pada saat itu lebih unggul dibanding dengan ikan lele lokal langsung mendapatkan tempat di hati para pembudidaya dan ternak ikan lele dumbo di nusantara. Ikan lele dumbo (Clarias gariepinus) termasuk salah satu jenis ikan yang banyak diminati oleh masyarakat (konsumen) karena mudah diolah, bergizi tinggi dan rasanya enak. Ikan lele dumbo (Clarias gariepinus) mudah dipelihara (diproduksi), disimpan dan dipasarkan. Baik berupa ikan hidup maupun ikan segar (Harsono dan Djarijijah, 2002).

Perikanan adalah suatu kegiatan perekonomian yang memanfaatkan sumberdaya alam perikanan dengan menggunakan ilmu pengetahuan dan teknologi untuk kesejatraan manusia, dengan mengoptimalisasi dan memelihara sumberdaya perikanan dan kelestarian lingkungan. Hasil perikanan merupakan hasil protein tinggi, murah dan mudah diperoleh. Produksi hasil perikanan ini masih sangat mungkin ditingkatkan, baik untuk tujuan konsumsi maupun ekspor. Dalam menghadapi tantangan persaingan yang semakin ketat dan menjaga kepercayaan konsumen terhadap suatu produk hasil perikanan, perusahaan dan para peternak atau pihak dalam pemasaran hasil perikanan harus selalu menjaga mutu produk yang dihasilkan. Mutu memang peranan penting bagi pihak-pihak tertentu atau perusahaan dalam menghasilkan produk andalannya dalam menghadapi tuntutan persaingan pasar yang sangat ketat. (Direktorat Jendral Perikanan, 2000).

Pembinaan mutu dan pengolahan hasil merupakan salah satu kegiatan pasca panen benih ikan maupun ikan konsumsi yang sangat penting dalam menunjang keberhasilan pembangunan perikanan karena dengan pembinaan mutu dapat menyelamatkan hasil produksi para petani dan nelayan ikan dari kemerosotan mutu dan nilainya yang sekaligus juga dapat meningkatkan pendapatan dan melindungi para konsumen dari hal-hal yang tidak diinginkan seperti kerugian yang merugikan para konsumen (Direktorat Jendral Perikanan, 2000).

Distribusi hasil perikanan adalah rangkaian kegiatan penyaluran hasil perikanan dari suatu tempat ke tempat lain sejak produksi, pengolahan sampai 
pemasaran. Hal yang paling prinsip dalam proses distribusi hasil perikanan adalah mempertahankan kondisi alat/wadah/sarana yang digunakan dalam proses distribusi agar produk yang didistribusikan sampai ke tempat tujuan dengan tetap mempertahankan mutu/kualitasnya. Oleh karena itu, distributor/penyalur hasil perikanan harus memahami persyaratan yang harus dipenuhi dalam proses distribusi hasil perikanan (Direktorat Jendral Perikanan, 2000)

Packing merupakan bagian dari seluk beluk keseluruhan pada proses produksi mulai dari pengadaan alat-alat dan bahan baku, cara Packing benih ikan maupun pengemasan menjaga mutu produksi saat penanganan berlangsung. Merupakan salah satu metode penanganan hasil perikanan baik budidaya ataupun tangkap yang sering dikenal dengan kegiatan (aktivitas) pasca panen.

Packing adalah suatu proses atau pembungkusan suatu produk dengan mengunakan bahan-bahan seperti plastik, polybag dan kardus untuk menghindari produk dari bahaya kontaminasi atau sinar matahari dan benturan. Proses Packing terdiri dari kegiatan (aktivitas) paska panen adalah suatu kegiatan yang tidak dapat dipisahkan dari kegiatan produksi perikanan. Peningkatan produksi perikanan yang tidak diikuti dengan penanganan pasca panen dapat menjadi masalah dalam pembangunan dan pengembangan pemasaran hasil perikanan (Khairuman dan Amri, 2002).

Proses Packing terjadinya kegiatan Packing di Balai Riset Budidaya Air Tawar Sekolah Tinggi Sibolga. Hal ini disebabkan adanya permintaan benih ikan lele dumbo (Clarias gariepinus) dari berbagai daerah, salah sataunya dari Kota Pinang. Sehingga peneliti ingini mengetahui berapa kepadatan atau kapasitas Packing yang tetap dan ideal untuk mencapai Kota Pinang dengan jarak tempuh selama 8 Jam dengan menggunakan wadah pengiriman kantong plastik. Menurut Khairuman dan K. Amri, (2002) setiap kantongan plastik ukuran 40 x $60 \mathrm{~cm}$ sebagai wadah atau media pengakutan. Setiap kantong plastik diisi air bersih sebanyak 10-15 liter dan jumlah oksigen sebanyak dua pertiga bagian dari kantong plastik. Setiap kantong plastik ukuran 40 x 60 dapat diisi sebanyak 500700 ekor benih ikan lele dumbo (Clarias gariepinus) jika benihnya berukuran 3-5 $\mathrm{cm}$, dengan lama perjalanan 4-6 Jam.

$$
\text { Efisiensi dan produktivitas }
$$

merupakan suatu ukuran tentang seberapa efisien suatu proses mengkonsumsi masukan dan seberapa produktif suatu proses menghasilkan keluaran. Efisiensi merupakan rasio antara keluaran dengan masukan suatu proses, dengan fokus perhatian pada konsumsi masukan. Produktivitas merupakan rasio antara masukan dengan keluaran, dengan fokus perhatian pada keluaran yang dihasilkan oleh suatu proses.

Direktorat Jendral Perikanan, (2000). Mutu produk yang rendah mengakibatkan nilai jual yang rendah, juga merugikan para kosumen dan berbahaya bagi kesehatan manusia. mutu produk yang rendah akan mengakibatkan posisi produk tidak memiliki daya saing di kalangan kosumen dan pasar. Dengan melihat latar belakang di atas maka penulis mengambil kesmipulan bahwa, benih ikan lele dumbo (Clarias gariepinus) ataupun produk hasil perikanan baik dalam bentuk benih ikan lele dumbo (Clarias gariepinus), atau produk bahan olahan dari sumber budidaya maupun tangkap akan memiliki nilai ekonomis jika dapat dipasarkan dan memberi manfaat (keuntungan) bagi pembudidaya maupun pengelolah hasil perikanan.

\section{METODE}

Ikan lele dumbo (Clarias gariepinus) merupakan salah satu jenis ikan ekonomis penting di Indonesia. Ikan lele dumbo (Clarias gariepinus) hidup di air tawar dengan daerah penyebaran yang luas baik secara horizontal dan vertikal dan digemari banyak konsumen. Disamping sebagai salah satu sumber protein hewani bagi masyarakat, lele dumbo (Clarias gariepinus) juga merupakan komoditas yang dapat menunjang ekonomi rumah tangga. Ikan lele dumbo (Clarias gariepinus) mempunyai tingkat serapan pasar yang 
cukup baik, selain pasar dalam negeri juga terdapat peluang untuk pasar ekspor (Az-Zarnuji, 2011).

Packing adalah suatu cara untuk membuat ikan dalam kondisi nyaman, tidak rusak, mudah, praktis dan tidak mengganggu kondisi sekitarnya, yakni selama pengangkutan atau pengiriman. Kegiatan Packing harus dilakukan hatihati terutama untuk mengangkut ikan dalam kondisi hidup karena ikan ini harus mampu hidup dan kondisi fisiknya bagus sampai ke pembeli.

Pengangkutan ikan hidup pada dasarnya adalah menempatkan ikan pada suatu lingkungan yang berbeda dengan lingkungan asalnya. Perbedaan tersebut diusahakan sekecil mungkin agar ikan yang diangkut dapat hidup sampai ke tempat tujuan atau paling tidak memperkecil tingkat kematian selama pengangkutan. Mengingat adanya permintaan benih ikan lele dumbo (Clarias gariepinus) dari Kota Pinang Kabupaten Labuhan Batu Selatan, sehingga penelitian ini dilakukan untuk mengetahui berapa kapasitas Packing yang ideal. Dengan lama perjalanan dari Kota Sibolga ke Kota Pinang yaitu 7-8 Jam.

Penelitian ini bertujuan untuk membandingkan dan menentukan jumlah benih ikan lele dumbo (Clarias gariepinus) yang ideal terhadap kapasitas Packing yang berbeda dengan tujuan yang sama dan untuk mengetahui berapa lama kah ikan lele dumbo (Clarias gariepinus) bertahan selama pengiriman. Berdasarkan uraian teori di atas hipotesis dalam penelitian diatas sebagai berikut : $\mathrm{H}_{0}$ : Tidak ada pengaruh yang signifikan pada kapasitas Packing benih ikan lele dumbo (Clarias gariepinus). $\mathrm{H}_{1}$ : Ada pengaruh yang signifikan pada kapasitas Packing benih ikan lele dumbo (Clarias gariepinus). Adapun beberapa peralatan dan bahan-bahan dalam proses pemasaran benih ikan lele dumbo (Clarias gariepinus) dapat dilihat pada Tabel 1 dan Tabel 2 di bawah ini:

Table 1. Alat-alat Penelitian Packing benih ikan lele dumbo (Clarias gariepinus)

\begin{tabular}{lll}
\hline No & Alat & Kegunaan \\
\hline 1 & Ember & $\begin{array}{l}\text { Wadah pemindahan atau penyortiran benih ikan lele } \\
\text { dumbo (Clarias gariepinus) }\end{array}$ \\
2 & Seser & $\begin{array}{l}\text { Untuk mengambil dan menangkap benih ikan lele } \\
\text { dumbo (Clarias gariepinus) }\end{array}$ \\
3 & Plastik & $\begin{array}{l}\text { Untuk tempat benih ikan lele dumbo (Clarias } \\
\text { gariepinus) yang akan Packing }\end{array}$ \\
4 & $\begin{array}{l}\text { Kamera dan } \\
\text { Alat Tulis }\end{array}$ & $\begin{array}{l}\text { Alat dokumentasi } \\
\text { Alat transportasi untuk pengiriman benih ikan lele } \\
\text { dumbo (Clarias gariepinus) }\end{array}$ \\
\hline & Sepeda Motor & \multicolumn{1}{c}{ Sumber : Data Primer, 2016 }
\end{tabular}

Tabel 2. Bahan yang digunakan

\begin{tabular}{llll}
\hline No & Bahan & Kegunaan \\
\hline 1 & $\begin{array}{l}\text { Benih ikan lele dumbo } \\
\text { (Clarias gariepinus) } \\
\text { Ukuran benih ikan lele } \\
\text { dumbo } \\
\text { gariepinus) }\end{array}$ & Sebagai bahan objek penelitian \\
3 & Tabung Oksigen & $\begin{array}{l}\text { Sebagai pembantu pernapasan benih ikan lele } \\
\text { dumbo (Clarias gariepinus) supaya bertahan } \\
\text { dalam kantong plastik Packing }\end{array}$ \\
\hline
\end{tabular}


Sumber : Data Primer,

\begin{abstract}
Metode penelitian yang dilakukan adalah metode penelitian dengan melakuakan percobaan (eksperimen) dengan 3 perlakuan dan 3 ulangan, yaitu : 1) Perlakuan 1: $P_{1}\left(P_{1.1}, P_{1.2}, P_{1.3}\right)$ dengan
\end{abstract}

jumlah 1.000 ekor; 2) Perlakuan 2: $P_{\|}$ $\left(P_{1.1}, P_{1.2}, P_{1.3}\right)$ dengan jumlah 1.250 ekor; 3) Perlakuan 3: $P_{I I I}\left(P_{1.1}, P_{1.2}, P_{1.3}\right)$ dengan jumlah 1.500 ekor

Tabel 3. Perlakuan Packing terhadap ikan lele dumbo (Clarias gariepinus) selaku objek penelitian

\begin{tabular}{ll}
\hline Kode perlakuan & Perlakuan \\
$\mathrm{P}_{I}$ & 1.000 ekor \\
$\mathrm{P}_{\|}$ & 1.250 ekor \\
$\mathrm{P}_{I I I}$ & 1.500 ekor \\
\hline & Sumber : Data Primer 2016
\end{tabular}

Adapun prosedur kerja yang akan dilakukan dalam penelitian ini sebagi berikut: 1) Persiapan wadah penelitian, wadah yang digunakan dalam penelitian ini yaitu kantong plastik dengan $100 \times 60$ $\mathrm{cm}$, ukuran $50 \mathrm{~kg}$ sebanyak 3 kantong plastik tersebut yang akan digunakan dalam penelitian ini; 2) Persiapan alan dan bahan, kelengkapan bahan sebelum pelaksanaan penelitian harus benar-benar diperhatikan agar dalam pelaksanaan penelitian bahan dan alat yang diperlukan maupun yang akan digunakan tidak ada kekurangan apapun, untuk keberhasilan penelitian yang akan dilaksanakan; 3) Pengadaan benih ikan lele dumbo (Clarias gariepinus), benih ikan lele dumbo (Clarias gariepinus) sebagai objek penelitian ini yang diperoleh dari Balai Riset Budidaya Air Tawar Sekolah Tinggi Perikanan Sibolga. Benih ikan lele dumbo (Clarias gariepinus) yang akan digunakan sebayak 11.250 ekor; 4) Packing, packing objek penelitiab dalam 3 wadah berukuran sama dengan jumlah yang berbeda-beda;
5) Dengan cara packing yang akan dilakukan yaitu : a) Wadah atau kantong plastik pertama berkapasitas 1.000 ekor; b) Wadah atau kantong plastik yang kedua berkapasitas 1.250 ekor; c) Wadah atau kantong plastik yang ketiga berkapasitas 1.500 ekor.

Data yang diperoleh diambil untuk menentukan tingkat kelangsungan hidup dan di analisis dalam sidik ragam dengan uji statistik pada selang kepercayaan 95\% untuk menentukan apakah perlakuan berpengaruh untuk kelangsungan hidup benih ikan lele dumbo (Clarias gariepinus). Bila nilai $F_{\text {hitung }}>F_{\text {tabel }}$ maka hipotesis $\mathrm{H}_{0}$ ditolak dan $\mathrm{H}_{1}$ diterima jika nilai $F_{\text {hitung }}<F_{\text {tabel }}$ maka hipotesis $\mathrm{H}_{0}$ diterima dan $\mathrm{H}_{1}$ ditolak. Untuk menguji tingkat keberhasilan benih ikan lele dumbo (Clarias gariepinus) pengaruh antara perlakuan dengan menggunakan uji SR (Survival Rata). Kelangsungan Hidup (SR) adalah tingkat perbandingan jumlah ikan yang hidup pada akhir dan awal penelitian.

Tabel 4. Jumlah benih ikan lele dumbo (Clarias gariepinus) yang akan dijadikan sampel

\begin{tabular}{llll}
\hline No & \multicolumn{1}{c}{ Kapasitas Packing } & $\begin{array}{c}\text { Jumlah benih ikan } \\
\text { lele dumbo (Clarias } \\
\text { gariepinus) }\end{array}$ & $\begin{array}{c}\text { Tingkat } \\
\text { keberhasilan } \\
\text { hidup }\end{array}$ \\
\hline 1 & Kantong Pastik yang pertama & 1.000 \\
2 & Kantong Pastik yang kedua & 1.250 & \\
3 & Kantong Pastik yang ketiga & 1.500 & \\
Total & 3 & 3.750 & \\
\hline
\end{tabular}

Sumber : Data primer, 2016 


\section{HASIL DAN PEMBAHASAN}

Balai Riset Sekolah Tinggi

Perikanan Sibolga berada di Desa

Rawang Kecamatan Tukka Kabupaten Tapanuli Tengah, yang didirikan pada tahun 2014 dengan luas $1 / 4$ ha. Dapat dikunjungi dengan kendaraan roda dua dan roda empat, dengan jarak tempuh \pm $1 \mathrm{~km}$ dari kantor camat tukka dan \pm 20 $\mathrm{km}$ dari kota Sibolga. Iklim di Kabupaten Tapanuli Tengah pada umumnya yaitu type A menurut klasifikasi Oldeman (hangat dengan temperatur $21,40^{\circ} \mathrm{C}-33^{\circ}$ c ). Dengan adanya Balai Riset Sekolah Tinggi Perikanan Sibolga saat ini sudah banyak digunakan oleh mahasiswa/i untuk melakukan praktek kerja lapangan seperti pengembangan dan penerapan tehnik pembenihan, pembudidayaan, serta penyediaan bibit ikan. Demikian juga halnya untuk proses penelitian mahasiswa/i dalam rangka penulisan skripsi. Adapun fasilitas yang tersedia di Balai Riset Sekolah Tinggi Perikanan Sibolga, relatif sudah memadai. Fasilitas tersebut terdiri dari sarana pokok dan sarana penunjang. Sehingga sangat membantu kepada para mahasiswa/i yang melakukan praktek kerja lapangan dan penelitian. Sarana pokok berfungsi untuk kegiatan yang bersifat operasional, sedangkan sarana penunjang merupakan sarana yang bersifat mendukung terhadap kegiaatan operasi pembudidayaan. Adapun sarana pokok dan sarana penunjang yang ada di Balai Riset Sekolah Tinggi Perikanan Sibolga, dapat dilihat sebagaimana disajikan pada tabel di bawah ini.

Tabel 5. Sarana pokok di Balai Riset Sekolah Tinggi Perikanan Sibolga

\begin{tabular}{llccc}
\hline No & \multicolumn{1}{c}{ Nama Kolam } & Pemijahan & $\begin{array}{c}\text { Kegunaan } \\
\text { Pendederan }\end{array}$ & Pembesaran \\
\hline 1 & Permanen 5 unit & - & - & 5 \\
2 & Semi permanen 5 unit & - & 1 & 4 \\
3 & Tanah 5 unit & 10 & 24 & 10 \\
\hline
\end{tabular}

Wadah yang digunakan dalam penelitian ini adalah kantong plastik dengan ukuran $100 \times 60$ (50) kg sebayak 3 kantong plsatik tersebut dan oksigen yang akan digunakan dalam penelitian ini. Pengiriman menggunakan kantong plastik mungkin pilihan terbaik untuk pengirim karena beberapa alasan : 1) Karena harganya sangat terjangkau; 2) Ikan sangat kecil dan dapat rusak jika dikirim dengan tangki besar; 3) Karena jarak yang sangat jauh sehingga dapat menekan biaya pengiriman. Media yang digunakan dalam penelitian ini adalah air bersih, di mana air bersih yang digunakan adalah air yang bersumber dari pengunungan. Penggunaan air dalam hal ini yaitu sebagai media tempat hidupnya ikan lele dumbo (Clarias gariepinus). Bahan uji yang digunakan dalam penelitian ini yaitu benih ikan lele dumbo (Clarias gariepinus). Benih ikan lele dumbo (Clarias gariepinus) yang digunakan merupakan hasil pemijahan dari Balai Riset Budidaya Air Tawar Sekolah Tinggi Perikanan Sibolga. Pengambilan benih ikan ikan lele dumbo (Clarias gariepinus) pada saat dilakukan penyortiran guna untuk keseragaman ukuran benih yaitu ukuran $3-5 \mathrm{~cm}$ yang digunakan dalam penelitian ini dianggap sama. Prinsip dalam pengangkutan ikan adalah bagaimana menciptakan suasana dalam alat pengangkutan agar ikan bisa bernapas dengan baik, sehingga bisa bertahan hidup hingga sampai di tujuan. Satu hal lagi yang harus menjadi perhatian adalah selama pengangkutan ikan mengeluarkan kotoran.

Packing adalah suatu atau cara untuk membuat ikan lele dumbo (Clarias gariepinus) dalam kondisi nyaman, tidak rusak, mudah, praktis dan tidak mengganggu kondisi sekitarnya, yakni selama pengangkutan atau pengiriman. Kegiatan pengamasan harus dilakukan dengan ke hati-hati terutama untuk mengangkut ikan lele dumbo (Clarias 
gariepinus) dalam kondisi hidup karena ikan lele dumbo (Clarias gariepinus) ini harus mampu hidup dan kondisi fisiknya bagus sampai ke pembeli atau kosumen. Packing merupakan penangan benih ikan lele dumbo (Clarias gariepinus) setelah panen dengan tujuan untuk tetap terjaga dan benih-benih lele dumbo (Clarias gariepinus) hidup sampai kepada para konsumen atau agen. Langkah awal yang dilakuka dalam proses packing adalah sebagai berikut : 1) Persiapan alat dan bahan yang akan digunakan dalam proses packing seperti, seser, ember sortiran, kantong plastik, karet, oksigen dan air bersih; 2) Benih ikan lele dumbo (Clarias gariepinus) sebagai objek penelitian dan kantong plastik sebagai wadah penelitian; 3) Proses packing terhadap benih ikan lele dumbo (Clarias gariepinus) dimulai dari penangkapan benih ikan lele dumbo (Clarias gariepinus) kemudian disortir. Kantong plastik harus dilapis dua tiap satu packing supaya kantong plastik tidak bocor. Dan metode seperti ini akan dilakukan setiap ulangan dan perlakuan; 4) Setelah selesai di packing benih ikan lele dumbo (Clarias gariepinus) tersebut diantar langsung ke kosumen dengan menggunakan sepeda motor.

Sortasi, atau seleksi dan penyortiran merupakan salah satu hal yang biasanya rutin dilakukan oleh pembudidaya baik ikan lele dumbo (Clarias gariepinus), maupun jenis ikan lainnya terutama para pembudidaya yang kegiatannya membudidayakan khususnya dalam hal pembenihan. Kegiatan seleksi sangat baik untuk keperluan pemerataan, atau pun untuk keperluan lainnya. Namun biasanya ada banyak kesalahan yang dilakukan oleh para pembudidaya yaitu, saat melakukan penyortiran benih ikan lele dumbo (Clarias gariepinus) baik di kolam galian tanah ataupun kolam terpal, khususnya pembenihan ikan lele dumbo (Clarias gariepinus). Tujuan penyortiran ini untuk memisahkan ukuran yang kecil dari ukuran yang besar. Karena benih ikan lele dumbo (Clarias gariepinus) tersebut ukurannya tida rata atau sama. Karena permintaan konsumen ukun 3-5 cm kita harus memilih benih ikan lele dumbo (Clarias gariepinus) yang ukurannya sesuan dengan permintaan para konsemen yaitu benih ukuran $3-5 \mathrm{~cm}$. Sesudah selesai disortir benih-benih ikan tersebut kemudia dihitung. Guna untuk menentukan berapa ekor benih ikan dalam setip kantongan plsatik atau dalam packing. Karena di dalam setiap kantong plastik kepadatannya berbeda mulai dari kantongan pertama 1.000 ekor dan kantongan yang kedua 1.250 sedangkan kantong plastik yang ketiga 1.500 ekor dengan lama jarak tumpuh atau perjaalnan selama 8 Jam.

Air merupakan faktor terpenting dalam budidaya ikan. Bukan hanya ikan lele dumbo (Clarias gariepinus), ikan-ikan lain pun untuk hidup dan berkembang biak memerlukan air. Tanpa air ikan tidak akan dapat hidup. Kualitas air adalah variabelvariabel yang dapat mempengaruhi kehidupan ikan lele dumbo (Clarias gariepinus). Kantongan plastik yang akan digunakan diisi dengan air bersih kira-kira 15-20 liter. Pada saat melakukan penelitian, air yang digunakan sebanyak 18 liter perkantong plastik dan berisi benih ikan lele dumbo (Clarias gariepinus) 1.000-1500 ekor.

$\begin{aligned} \text { Volume air } & =\mathrm{P} \times \mathrm{L} \times \mathrm{T} \\ & =100 / 100 \times 60 / 100 \times\end{aligned}$

$25 / 100$

$$
\begin{aligned}
& =1 \times 0.6 \times 0.25 \\
& =0.15 \mathrm{~m}^{3}
\end{aligned}
$$

Ukuran satuan liter dari $1 \mathrm{~m}^{3}$ sama dengan 1000 liter.

Jadi $\quad=0.15 \mathrm{~m}^{3}=15$ liter air di setiap packing.

Cara packing ikan lele dumbo (Clarias gariepinus) yang akan dikirimkan merupakan bagian yang terpenting yang harus diperhatikan saat proses packing benih ikan lele dumbo (Clarias gariepinus) yang telah dipesan oleh konsumen dilakukan melalui beberapa tahapan cara yang baik dan sangat terjaga, adalah sebagai berikut : 1) Benih ikan lele dumbo (Clarias gariepinus) yang dipesan dipilih yang sehat, yaitu tidak cacat dan bebas dari penyakit dan parasit. Selanjutnya benih ikan lele dumbo (Clarias gariepinus) dimasukkan ke dalam kantong plastik kemudian di isi oksigen; 2) Air yang digunakan sebagai media pengangkutan bersih, sehat, bebas hama dan penyakit serta bahan organik lainya; 3) Sebelum 
diangkut benih ikan lele dumbo (Clarias gariepinus) terlebih dahulu diberok selama satu hari dalam bak yang berisi air bersih dan dengan aerasi yang baik. Tujuannya agar benih ikan lele dumbo (Clarias gariepinus) tidak terlalu banyak membuang kotoran pada saat dalam kantongan plastik. Berdasarkan lama atau jarak pengiriman dari Tukka-Kota Pinang, maka sistem pengangkutan atau pengiriman benih ikan dilakukan dengan cara yaitu, dengan sistem tertutup dilakukan untuk mengangkut benih dalam jarak jauh atau membutuhkan waktu yang cukup lama hingga 7-8 Jam. Pengangkutan sistem tertutup ini sangat cocok diterapkan untuk pengiriman jarak jauh atau pun antar pulau. Hanya saja, faktor oksigen merupakan hal yang mutlak dibutuhkan. Suhu media secara fisik berpengaruh pada tingkat kelarutan oksigen di dalam air, semakin dingin suhu air, konsentrasi oksigen terlarut akan semakin tinggi.

Kandungan oksigen dalam pengangkutan benih ikan lele dumbo (Clarias gariepinus) sangat erat hubungannya dengan kepadatan, jumlah benih ikan lele dumbo (Clarias gariepinus), dan lamanya waktu pengangkutan. Jika oksigennya sedikit, jumlah benih ikan lele dumbo (Clarias gariepinus) yang ditampung dalam media juga sedikit dan waktu angkut pun menjadi singkat. Pada saat melakuan packing tidak menggunakan oksigen benih ikan lele dumbo (Clarias gariepinus) tidak akan tahan lama, hanya 2-3 Jam. Karena didalam kantong plastik benih ikan lele dumbo (Clarias gariepinus) akan kekurangan oksigen sehingga benih ikan tersebut mudah stress kemudian berputarputar kepermukaan air sehingga akan mengakibatka benih ikan tersebut akan mati. Packing yang menggunakan oksigen benih ikan lele dumbo (Clarias gariepinus) tidak mudah stress dan akan tahan selama pengiriman 7-8 Jam perjalanan. Pengisian oksigen pada saat melakukan penelitian proses packing setelah diisi benih ikan lele dumbo (Clarias gariepinus) kemudian mengisi oksigen secukupnya sampai kantong plastik penuh. Kemudian ujung kantong plastik diputar dan diikan dengan karet sampai oksigen didalam kantong plastik tersebut tidak keluar.

Menurut Khairuman dan K. Amri, (2002) setiap kantongan plastik ukuran 40 $x \quad 60 \mathrm{~cm}$ sebagai wadah atau media pengakutan. Setiap kantong plastik diisi air bersih sebanyak 10-15 liter dan jumlah oksigen sebanyak dua pertiga bagian dari kantong plastik. Setiap kantong plastik ukuran 40 x 60 dapat diisi sebanyak 500700 ekor benih ikan lele dumbo (Clarias gariepinus) jika benihnya berukuran 3-5 $\mathrm{cm}$, dengan lama perjalanan 4-6 Jam. Pengadaan benih ikan lele dumbo (Clarias gariepinus) pada awal penelitian kita bisa melihat pada tabel di bawah ini :

Tabel 6. benih ikan lele dumbo (Clarias gariepinus)

\begin{tabular}{ccccc}
\hline \multicolumn{5}{c}{ Awal Penelitian } \\
\hline Ulangan & Packing I & Packing II & Packing III & \\
\hline 1 & 1.000 & 1.250 & 1.500 & \\
2 & 1.000 & 1.250 & 1.500 & \\
3 & 1.000 & 1.250 & 1.500 & $\mathbf{1 1 . 2 5 0}$ \\
\hline Jumlah & $\mathbf{3 . 0 0 0}$ & $\mathbf{3 . 7 5 0}$ & $\mathbf{4 . 5 0 0}$ & \\
\hline Rata-rata & $\mathbf{1 . 0 0 0}$ & $\mathbf{1 . 2 5 0}$ & $\mathbf{1 . 5 0 0}$ & \\
\hline & & & Sumber : Data primer 2016
\end{tabular}

Dari hasil tabel di atas benih ikan lele dumbo (Clarias gariepinus) di awal penelitian di anggap $100 \%$. Berdasarkan penelitian yang dilakukan, tingkat kelangsungan hidup benih ikan lele dumbo (Clarias gariepinus) tertinggi terdapat pada perlakuan $\left(\mathrm{P}_{\mathrm{I}}\right)$ yaitu $98.83 \%$ kemudian disusun perlakuan ke dua $\left(P_{\|}\right)$ yaitu $98.29 \%$ dan yang terendah terdapat pada perlakuan ke tiga $\left(P_{\text {III }}\right)$ yaitu $97.55 \%$. Tingkat kelangsungan hidup benih ikan 
lele dumbo (Clarias gariepinus) (SR)

dapat kita lihat pada tabel di bawah ini :

Tabel 7. Rata-rata presentase tingkat kelangsungan hidup benih ikan lele dumbo (Clarias gariepinus) selama melakukan penelitian

\begin{tabular}{ccccc}
\hline \multicolumn{5}{c}{ Perlakuan } \\
\hline Ulangan & Packing I & Packing II & Packing III & \\
\hline 1 & 99.10 & 98.16 & 97.13 & \\
2 & 98.80 & 98.40 & 97.80 & \\
3 & 98.60 & 98.32 & 97.66 & \\
\hline Jumlah & $\mathbf{2 9 6 . 5 0}$ & $\mathbf{2 9 4 . 8 8}$ & $\mathbf{2 9 2 . 5 9}$ & $\mathbf{8 8 3 . 9 7}$ \\
\hline Rata-rata & $\mathbf{9 8 . 8 3}$ & $\mathbf{9 8 . 2 9}$ & $\mathbf{9 7 . 5 3}$ & \\
\hline & & & Sumber : Data primer 2016
\end{tabular}

Keterangan: Perhitungan data pada tabel diatas dapat dilihat pada lampiran. Dari hasil pengamatan Survival Rate (SR) pada tabel diatas, maka dapat dihasilkan histogram Survival Rate (SR) di mana tingkat kelangsungan hidup benih ikan lele dumbo (Clarias gariepinus) di atas, dapat dibuat dalam histogram tingkat kelangsungan hidup benih ikan lele dumbo (Clarias gariepinus) seperti di bawah ini :

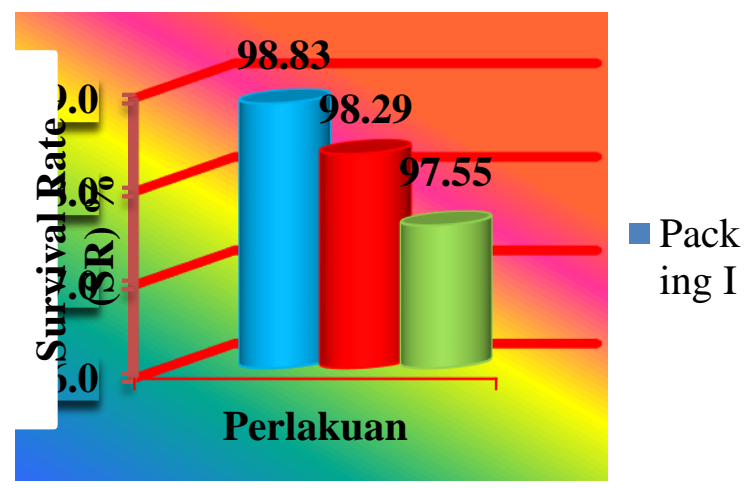

Gambar 1 : Histogram survival rate (SR) tingkat kelangsungan hidup benih ikan lele dumbo (Clarias gariepinus)

Berdasarkan histogram di atas dapat diketahui bahwa presentase nilai tingkat kelulusan hidup benih ikan lele dumbo (Clarias gariepinus) (SR) terdapat pada perlakuan pertama $\left(P_{\mathrm{I}}\right)$ dengan nilai $98.83 \%$ dan disusul perlakuan ke dua $\left(\mathrm{P}_{\|}\right)$ dengan nilai $98.29 \%$ dan nilai terendah yaitu perlakuan ke tiga ( $\mathrm{P}_{\mathrm{III}}$ ) dengan nilai $97.55 \%$. Berdasarkan hasil analisis sidik ragam pada selang kepercayaan 95\% dengan menggunakan model Rancangan Acak Lengkap (RAL), pengaruh perlakuan benih ikan lele dumbo (Clarias gariepinus) terdapat persentase kelulusan hidup benih ikan lele dumbo (Clarias gariepinus) menunjukan bahwa $F_{\text {hitung }}>F_{\text {tabel }}$ $(18.99639>5.143253)$ artinya hipotesis $\mathrm{H}_{0}$ ditolak dan $\mathrm{H}_{1}$ diterima. Untuk menguji tingkat keberhasilan kelulusan hidup benih ikan lele dumbo (Clarias gariepinus) pengaruh antara perlakuan dengan menggunakan uji SR (Survival Rate) menunjukkan bahwa terdapat pengaruh yang signifikan antara perlakuan.

\section{SIMPULAN dan SARAN}

Simpulan

Dari hasil penelitian yang telah dilakukan dapat diambil kesimpulan sebagai berikut: 1) Packing yang ideal terdapa pada perlakuan pertama $\left(P_{1}\right)$ dimana kepadatan packing yaitu 1.000 ekor, dengan kelulusan hidup benih ikan lele dumbo (Clarias gariepinus) mencapai $98.83 \%$; 2) Packing yang efesien terdapat di $\left(P_{3}\right)$ dengan kepadatan 1.500 bila dibandingkan dengan $\left(P_{1}\right) 1.000$ dan $\left(P_{2}\right)$ 1.250 ekor benih ikan lele dumbo (Clarias gariepinus). Karena setelah dilakukan perhitungan keuntungan lebih baik bila di bandingkan dengan $\left(P_{1}\right) 1.000$ dan $\left(P_{2}\right)$ 1.250.

Saran:

Kepada para pembudidaya ikan lele dumbo (Clarias gariepinus) sebelum melakukan packing agar tidak memberi makan selama $1 \times 24$ Jam. Supaya benih ikan lele dumbo (Claria gariepinus) tersebut tidak terlalu banyak mengeluarkan kotoran (amonia) di dalam kantong plasti, jika benih ikan banyak 
mengeluarkan kotoran sehingga binihbenih ikan tersebut mudah stress dan mati. Kepada peneliti lanjutan disarankan untuk melakukan penelitian dengan kepadatan isi per packing 2.000-3.000 ekor dengan jarah tempuh 10 - 12 Jam, supaya mendapatkan hasil yang lebih efisien.

\section{DAFTAR PUSTAKA}

Andrianto,T.T., dan Indarto Novo. 2005. Pedoman Praktis Budidaya Ikan Lele. Absolut. Yogyakarta.

Affandi, R. dan Usmar.2002. Fisiolgi Hewan Air. Pekanbaru. Riau. Indonesia. 217 hal.

Akbar, S. 2000. Meramu Pakan Ikan Kerapu. Penebar Swadaya, Jakarta.

Alma, Bukhari. Daniel 2004. Manejemen Pemasaran dan pemasaran jasa. Bandung. Penerbit : Alfabeta.

Arifin, Z. 1999. Budidaya Ikan Lele (Clarias gariepinus). Effhar.

Semarang.

Az-Zarnuji. 2011. "Analisis Efisiensi Budidaya Ikan Lele Di Kabupaten Boyolali (Studi Kasus di Kecamatan Sawit Kabupaten Boyolali)". Skripsi Universitas Diponegoro: Semarang.

Bachtiar, 1995.Paduan Lengkap Budidaya IkanLele Dumbo.Agro Media Pustaka. Jakarta.

Boyd, C.E. 1990. Water Quality in Ponds for aquaculture. Alabama. Auburn University.

Direktorat Jendral Perikanan. 2000a. Konsepsi Dasar Pendoman Penerapan Manejemen Mutu Terpadu (PMMT) BERDASARKAN KONSEPSI HCCP Modul I. Direktorat Usaha dan Pengelolaan Hasil Dirjen Perikanan. Jakarta.

Effenddie, M. I. 2002 Biologi Perikanan. Yayasan Nusantara. Bogor 112 hal.
, I. 1997. Biologi Perikanan. Yayasan Pustaka Nusantara. Bogor.

Hanafiah. 2008. Rancangan Percobaan Teori dan Aplikasi. Jakarta : PT Raja Grafindo Persada

Hanafie, R. 2010 Pengantar Ekonomi Pertanian. Yogyakarta : Andi Yogyakarta.

Harsono dan Djarijah, 2002. Pembenihan dan Pembesaran Ikan Lele Hemat Air. Kanisius, Yogyakarta.

Khairuman, 2002. Budidaya Lele Dumbo Secara Intensif. Argo Media Pustaka. Jakarta.

Khairul Amri, Khairuman. 2002. Pengemasan (Packing) dalam Buku Budidaya Lele Secara Intensif. Agromedia Pustaka. Jakarta

Kotler P. Manejemen Pemasaran di Indonesia. Edisi 1. Jakarta : Salemba Empat. 1999 : 52 Kevin Keller, 2008. Manejemen Pemasaran, Jilit 1, Penerbit Erlangga. Jakarta.

Kordi, M. Ghufran daan AB. Tancung. 2007. Pengelolaan Kualitas

Air dalam Budidaya Perairan. Rineka Cipta. Jakarta.

Mahyudin, Kholis. 2008. Panduan Lengkap Agribisnis Lele. Penebar Swadaya. Jakarta.

Malayu S. P. Hasibuan. (1994) Manejemen Sumberdaya Manusia. Jakarta : Bumi Aksara.

Mulyadi. 2000. Akuntasi Biaya Edisi 5. Yogyakarta: Aditya Media.

Murni, Niat. 2015. Pengaruh Pemberian Jenis Pakan Alami 
Terhadap Laju Pertumbuhan Ikan Arwana Hijau (Scleropages formosus). Program Studi Budidaya Perairan. Sekolah Tinggi Perikanan Sibolga. Sibolga.

Nijayanti S, 1992. Memelihara ikan lele dumbo di kolam taman. Penebar Swadaya. Jakarta.

Lesmana, S. 2001. Kualitas Air untuk Ikan Hias Air Tawar. PT Penebar Swadaya. Jakarta.

Purwaningsih, Sri. 1998. Sistem Transportasi Ikan Hidup. Buletin Teknologi Hasil Perikanan. Fakultas Perikanan dan IImu Kelautan. Institut Pertanian Bogor. Bogor. Vol. V N0 1.2 hal

Prihartono, R. E. I. Rasidik dan U. Arie 2009. Mengatasi Permasalahan Budidaya Lele Dumbo. Penebar Swadaya. Jakarta.

Puspowardoyo dan Djairah, 2002. Pembenihan Lele Dumbo Hemat Air. Kanisius Yogyakarta.

Pusat Penyuluhan Kelautan dan Perikanan. 2011. Budidaya Ikan Lele. Departemen Perikanan dan Kelautan, Jakarta.

Ridwan Affandi, 2002, pembesaran Ikan Lele Dumbo Air Tawar. Konisius. Jakarta.

Santoso, Budi. 1995. Petunjuk Praktis Budidaya Ikan Lele Dumbo dan Lokal. Kanisius. Yokyakarta.

, Heru. 2002. Teknik Kawin Suntik Ikan Ekonomis. Penebar swdaya. Jakarta.

Sarwono. 2008. Klasifikasi Ikan Tawar. Jakarta. Penebar Swadaya Soetomo, M. 2000 Teknik Budidaya Dumbo. Sinar baru

Algensindo Bandung.

Spriyono, R. A, 2000. Akuntasi Biaya : Perencanaan dan Pengendalian Biaya Serta Pembuatan Keputusan, Edisi Kedua, BPFE, Yogyakarta.
Sudiyono, 2002. Pemasaran Pertanian. Universitas Muhammadiyah Malang. Malang. Suzuki T. 1981. Fish and Krill Protein. London : Processing Teehnology Applied Science Publishing. Ltd.

Suyanto. 2007. Budidaya Ikan Lele. Penebar Swadaya. Jakarta.

Zonneveld NEA, EA. Huissman dan JH. Boon. 1991. Prinsip-Prinsip Budidaya Ikan. Gramedia, Jakarta. 